\title{
Sweet Potato Gummy Sorption Isotherm: Product Development and Stability Analysis
}

\section{Isotermas de sorción de gomitas de batata: desarrollo del producto y análisis de estabilidad}

\section{Liliana Edith Vergara}

Grupo de Investigación en Biotecnología y Alimentos (BIOTEC), Universidad Tecnológica Nacional. Facultad Regional Resistencia. French 414, 3500, Resistencia, Chaco - Argentina.

levergara@hotmail.com

\section{María Victoria Traffano-Schiffo}

Grupo de Investigación en Biotecnología y Alimentos (BIOTEC), Universidad Tecnológica Nacional. Facultad Regional Resistencia. French 414, 3500, Resistencia, Chaco, Argentina.

Instituto de Química Básica y Aplicada del Nordeste Argentino, IQUIBA-NEA, UNNE-CONICET, Avenida Libertad 5460, 3400 Corrientes - Argentina.

victoriaschiffo@hotmail.com

\section{Sonia C. Sgroppo}

Instituto de Química Básica y Aplicada del Nordeste Argentino, IQUIBA-NEA, UNNE-CONICET, Avenida Libertad 5460, 3400 Corrientes - Argentina.

Laboratorio de Tecnología Química y Bromatología, Facultad de Ciencias Exactas, Naturales y Agrimensura, UNNE, Av. Libertad 5460, 3400 Corrientes - Argentina.

sonia.sgroppo@hotmail.com

\section{Carola A. Sosa}

Grupo de Investigación en Biotecnología y Alimentos (BIOTEC), Universidad Tecnológica Nacional. Facultad Regional Resistencia. French 414, 3500, Resistencia, Chaco - Argentina.

sosacarola48@gmail.com 


\title{
Resumen
}

El presente estudio trata sobre el desarrollo de una confitura (caramelo) tecno-funcional, en base a materias primas autóctonas de la región Chaqueña. A fin de analizar su vida útil, se determinaron las isotermas de sorción a 4, 20 y $30^{\circ} \mathrm{C}$. Se aplicaron numerosos modelos matemáticos para ajustar el comportamiento de sorción, siendo el modelo de Peleg el que más se ajustó a los datos experimentales. Los resultados obtenidos en el presente estudio, abren una oportunidad para futuros trabajos en los que el alimento desarrollado pueda ser utilizado como portador de compuestos funcionales como fibras, proteínas, compuestos bioactivos y colorantes naturales, entre otros.

Palabras clave: Confitura, Compuestos funcionales, Isoterma de sorción, Modelo de Peleg, GAB.

\begin{abstract}
The present study is about the development of a healthy confectionery (soft candy) based on native raw materials from Chaco Province. In order to analyze its shelf life, the sorption isotherms were determined at 4,20 and $30{ }^{\circ} \mathrm{C}$. Several mathematical models were applied to adjust the sorption behavior with Peleg's model being the one that best fit the experimental data. The results obtained in this study open an opportunity for future work in which the food developed can be used as a carrier of functional compounds such as fibers, proteins, bioactive compounds and natural dyes, among others.
\end{abstract}

Keywords: Confectionery, Functional compounds, Sorption isotherm, Peleg's model, GAB.

\section{Introduction}

Confectionery products are part of an extensive market consisting of a heterogeneous group of consumers, from children to elderly (de Moura, Berling et al., 2019). According to Martínez, (2012) more than 50\% of European adults regularly ingest candies and gum, while the most accepted in general, are gummies, jellies or soft candies. Gummies are very popular all over the world and it is estimated that the consumption in high-income countries is around $7 \mathrm{~kg}$ per person, while in low-income countries the consumption is lower but the market is growing constantly (Mutlu et al., 2018).

Gummies are produced in various shapes, colors, flavors, with a growing demand for textures and attractive appearances. Its preparation consists of mixtures of high amounts of sucrose-glucose syrups combined with gelling agents, acids, flavorings and dyes (Jiamjariyatam, 2018). They have a particular texture characterized by their elasticity and some chewiness conferred by the gelatin, starch or pectin gels included in their preparation (Burey et al., 2009). This textural characteristic is directly related to the water content, which plays a critical role during the manufacture and storage of the candies (Ergun, 2010).

One of the most useful tools that describe the relationship between food moisture and $\mathrm{a}_{\mathrm{w}}$ of the sample is the sorption isotherm (Traffano-Schiffo et al., 2016). It is highly important in food industry and food science to understand the interactions of the different components of the food matrix to predict its shelf-life, to determine its optimal conditions of storage and also for the design and optimization of drying equipment and packaging (Talens et al., 2018; Lemus, 2011). 
Several mathematical models have been developed to describe and predict the sorption behavior of food systems. Some of them have a theoretical basis while others are empirical, semi-empirical or a simplification of other more complex model (Lemus, 2011). The most used models are BET (Brunauer et al., 1938) and GAB (Van den Berg, 1984), because they had a thermodynamic meaning which can be described by three constants. Two of these correspond to BET model; $\mathrm{X}_{\mathrm{w} 0}$, the monomolecular moisture layer, and $\mathrm{C}$, the energy constant, which is related to the isosteric heat of sorption. The last parameter represents the strength of water molecules bonds to the primary binding sites of the surface of the sample, where higher values of $C$ indicate stronger bonds. Finally, the third constant $(K)$ is an empirical parameter which was included in GAB model (modified BET). This parameter considers water molecules of the multilayer (Talens et al., 2018; Traffano-Schiffo et al., 2015).

There are very interesting researches developed on candies and gummies focusing in the replacement of sugars by sweetener (Jiamjariyatam, 2018; Periche et al., 2016); and in the addition of bioactive compounds (de Moura et al., 2019, Otálora et al., 2019). However, nowadays there are no researches where the food matrix of the candy consists on a vegetable (healthy and with all the benefits and properties that a natural matrix can provide). In addition, there are no studies of the sorption behavior of the gummies. Thus, the main purpose of this research is to develop a gummy based on sweet potato and to determine the sorption isotherms applying different theoretical and empirical models.

\section{Materials and methods}

Sweet potatoes (Ipomoea batatas (L.) Lam) of the autochthonous variety of the northeast of Argentina called 'Colorada Correntina' were used. They were obtained from the Cooperativa de Provisión para Productores y Distribución Frutihortícola Nordeste Ltda., located in the wholesale market of Resistencia (Chaco, Argentina). Tubers were selected according to their homogeneity in their stage of maturity, color, shape, firm texture and free from damage. Commercial sucrose (AG SRL, Resistencia, Chaco); liquid commercial glucose-sucrose $83{ }^{\circ}$ Brix (Ciotti S.A., Bs. As., Argentina); honey supplied by a local apiculture producer Colmenares Stacul (Colmenares Stacul, Barranqueras, Chaco, Argentina) and gelatin 220 Bloom (Todo Droga, Buenos Aires, Argentina) were also used.

\section{Experimental procedure}

In order to obtain the gummies, the sweet potatoes were washed, peeled and cut into slices of $1 \mathrm{~cm}$ thickness. They were sanitized with sodium hypochlorite solution $(10 \mathrm{mg} / \mathrm{L})$ for $3 \mathrm{~min}$ and washed with tap water. The slices were cooked steamed for 15 minutes and then grinded using a high-speed Universal Desintegrator FW100 grinder (Huanghua Faithful Instrument Co., Tianjin, China) at $200 \mathrm{~W}$ and $24000 \mathrm{rpm}$, until obtaining a pureé without lumps. A mixture prepared with $15.80 \%(w / w)$ of sucrose, $22.35 \%(w / w)$ of liquid glucose-sucrose and $8.0 \%(\mathrm{w} / \mathrm{w})$ of tap water was used as sugar solution. The solution was stirred at $60{ }^{\circ} \mathrm{C}$ during $15 \mathrm{~min}$ and until its complete dissolution. For the gelling solution, $4.6 \%(\mathrm{w} / \mathrm{w})$ of gelatin was mixed with $11.76 \%(\mathrm{w} / \mathrm{w})$ of hot water and it was maintained at $60^{\circ} \mathrm{C}$ until its use. Gummy confection was carried out by mixing on one side the sweet potato puree and the honey in a relationship 50:50 (w/w); and on the other side, the gelatin with the sugar solution, keeping all solutions below $60^{\circ} \mathrm{C}$ in order to avoid the development of hydroxymethylfurfural and Maillard reaction. The mixture was molded and gelled at $4{ }^{\circ} \mathrm{C}$. Subsequently, the edible coating was applied.

The coating solution was prepared according the formulation suggested by Famá et al. 
(2004), based on an aqueous solution of cassava starch $(2.5 \% \mathrm{w} / \mathrm{v})$, potassium sorbate $(0.2$ $\% \mathrm{w} / \mathrm{v})$ and glycerol $(2.5 \% \mathrm{w} / \mathrm{v})$. The coating solution was mixed and heated at $75{ }^{\circ} \mathrm{C}$ with continuous stirring, until complete gelification of the starch. The coating was applied by immersing the gummies into the solution at $37.5^{\circ} \mathrm{C}$ and the final product was dried in a tray dryer with forced air convection at $20^{\circ} \mathrm{C}$ during $10 \mathrm{~h}$.

\section{Water sorption isotherm}

Water activity and water sorption isotherm was obtained applying the static gravimetric method standardized by the European Cooperative Project Cost 90 (Spiess \& Wolf, 1983). $5 \mathrm{~g}$ of the samples were weight with analytical balance Denver Instrument (with a precision of $\pm 0.001 \mathrm{~g}$ ) (Denver Instruments, New York, U.S.A). They were placed in hermetic chambers at 4, 20 and $30^{\circ} \mathrm{C}$ containing saturated salt solutions at different $\mathrm{a}_{\mathrm{w}}$ (Rizvi, 2014) (Table 1). The sample weights were controlled every three days until a constant value was reached. Thus, the equilibrium was assumed (Moraga et al., 2006). Measurements were performed in triplicate. In the case of high $\mathrm{a}_{\mathrm{w}}$ atmospheres, a certain amount of toluene was added to prevent the proliferation of microorganisms.

Water content was obtained gravimetrically by the difference in weight before and after drying in vacuum oven DZF 6020 model (ARCANO, Pomona, CA, U.S.A.) during $5 \mathrm{~h}$ at $70 \pm 1$ ${ }^{\circ} \mathrm{C}$ and $-100 \mathrm{mmHg}$ (AOAC 934.06). Water content determination was performed in duplicate.

\begin{tabular}{|c|c|c|c|}
\hline \multirow{2}{*}{ Salt } & \multicolumn{3}{|c|}{ Temperature } \\
\cline { 2 - 4 } & $4{ }^{\circ} \mathrm{C}$ & $20{ }^{\circ} \mathrm{C}$ & $30{ }^{\circ} \mathrm{C}$ \\
\hline $\mathrm{LiCl}$ & 0.113 & 0.113 & 0.113 \\
\hline $\mathrm{MgCl}_{2}$ & 0.336 & 0.330 & 0.324 \\
\hline $\mathrm{K}_{2} \mathrm{CO}_{3}$ & 0.431 & 0.432 & 0.432 \\
\hline $\mathrm{NaCl}$ & 0.758 & 0.754 & 0.751 \\
\hline $\mathrm{KCl}$ & 0.877 & 0.863 & 0.834 \\
\hline $\mathrm{KNO}_{3}$ & 0.975 & 0.940 & 0.923 \\
\hline $\mathrm{K}_{2} \mathrm{SO}_{4}$ & 0.985 & 0.973 & 0.970 \\
\hline
\end{tabular}

Table 1. $a_{w}$ of the saturated salt solutions at 5, 20 and $30^{\circ} \mathrm{C}$ (Adapted from Greenspan, 1977).

\section{Sorption isotherm modeling}

Sorption isotherms were fitted according eleven models: BET, GAB, Henderson, Halsey, Peleg, Oswin, Iglesias and Chirife, Smith, White and Eiring, Kuhn and Caurie. Table 2 shows the equations of the models used to fit the experimental data, their parameters and a brief summary of the meaning of each of them. Sorption isotherms were fitted by non-linear regression analysis of the experimental data using Prism 6 (GraphPad Software, San Diego, CA, USA). The determination coefficients $\left(\mathrm{R}^{2}\right)$ and the standard deviation of residuals (Sy.x) were used as a measure of the goodness of fit of the sorption models. Values of $\mathrm{R}^{2}$ close to 1.0 and small Sy.x values indicate better curve fitting (Guerrero-Coronilla et al., 2015). 


\begin{tabular}{|c|c|c|c|}
\hline Model & Mathematical equation & Paremeter & Reference \\
\hline BET & $X_{e}=\frac{X_{0} C a_{w}}{\left(1-a_{w}\right)\left(1+(C-1) a_{w}\right)}$ & $\begin{array}{c}\mathrm{X}_{0}: \text { monomolecular moisture } \\
\text { layer }\left(\mathrm{kg}_{\mathrm{w}} / \mathrm{kg}_{\mathrm{dm}}\right) \\
\mathrm{C} \text { : energy constant related } \\
\text { to the heat of sorption } \\
\text { (dimensionless) }\end{array}$ & $\begin{array}{l}\text { Brunauer, } \\
\text { Emmett, } \\
\text { Teller, (1938) }\end{array}$ \\
\hline GAB & $X_{e}=\frac{X_{0} C K a_{w}}{\left(1-K a_{w}\right)\left(1+(C-1) K a_{w}\right)}$ & $\begin{array}{c}\mathrm{X}_{0}: \text { monomolecular } \\
\text { moisture layer (kgw/kgdm) } \\
\text { C y K: energy constants } \\
\text { related to the heat } \\
\text { of sorption of the } \\
\text { monomolecular layer } \\
\text { (dimensionless) }\end{array}$ & $\begin{array}{c}\text { Van den Berg, } \\
(1984)\end{array}$ \\
\hline Henderson & $X_{e}=0,01\left(\frac{\log \left(1-a_{w}\right)}{10^{f}}\right)^{\frac{1}{n}}$ & $\begin{array}{l}\text { n y f: characteristic } \\
\text { parameters of the product } \\
\text { (dimensionless) }\end{array}$ & $\begin{array}{l}\text { Henderson, } \\
\text { (1952) }\end{array}$ \\
\hline Halsey & $X_{e}=\left(-\frac{A}{\ln a_{w}}\right)^{\frac{1}{B}}$ & $\begin{array}{l}\text { A and B: empirical } \\
\text { parameters }\end{array}$ & Halsey, (1948) \\
\hline Peleg & $X_{e}=A a_{w}^{B}+C a_{w}^{D}$ & $\begin{array}{c}A, B, C \text { and } D: \text { empirical } \\
\text { parameters }\end{array}$ & Peleg, (1993) \\
\hline Oswin & $X_{e}=A\left(\frac{a_{w}}{1-a_{w}}\right)^{B}$ & $\begin{array}{l}\text { A and B: empirical } \\
\text { parameters }\end{array}$ & Oswin, (1946) \\
\hline $\begin{array}{l}\text { Iglesias } \\
\text { and Chirife }\end{array}$ & $X_{e}=A+B\left(\frac{a_{w}}{1-a_{w}}\right)$ & $\begin{array}{l}\text { A and B: empirical } \\
\text { parameters }\end{array}$ & $\begin{array}{l}\text { Boquet, } \\
\text { Chirife, \& } \\
\text { Iglesias, } \\
\text { (1978) }\end{array}$ \\
\hline Smith & $X_{e}=A-B\left(\ln \left(1-a_{w}\right)\right)$ & $\begin{array}{l}\text { A and B: empirical } \\
\text { parameters }\end{array}$ & Smith, (1947) \\
\hline $\begin{array}{l}\text { White and } \\
\text { Eiring }\end{array}$ & $X_{e}=\frac{1}{\left(A+B a_{w}\right)}$ & $\begin{array}{l}\text { A and B: empirical } \\
\text { parameters }\end{array}$ & $\begin{array}{l}\text { Bahloul, } \\
\text { Boudhrioua, } \\
\text { \& Kechaou, } \\
\text { (2008) }\end{array}$ \\
\hline Kuhn & $X_{e}=\frac{A}{\ln a_{w}}+B$ & $\begin{array}{l}\text { A and B: empirical } \\
\text { parameters }\end{array}$ & Kühn, (1964) \\
\hline Caurie & $X_{e}=\exp \left(a_{w} \ln (r)-\frac{1}{4.5 X_{s}}\right)$ & $\begin{array}{l}\text { r: constant characteristic of } \\
\text { the material } \\
\mathrm{X}_{\mathrm{s}} \text { : safety moisture content } \\
\text { that provides maximum } \\
\text { stability to the dehydrated } \\
\text { food during storage }\left(\mathbf{k g}_{\mathrm{w}} /\right. \\
\left.\mathbf{k g}_{\mathrm{dm}}\right)\end{array}$ & Caurie, (1971) \\
\hline
\end{tabular}

Table 2. Sorption isotherms models for equilibrium moisture 


\section{Results and discussions}

Confectionary products are made with different ingredients and under different processing conditions. These factors directly affect the nature of the water they content and, consequently, the physical state of the matrix, the texture of the product and its stability during storage (Ergun et al., 2010). Sorption isotherms are considered as a very effective tool that describes the relationship between the water activity of the samples and their moisture (in dry basis) at a constant temperature (Traffano-Schiffo et al., 2015). They allow to predict the chemical and the enzymatic reactions and the possible microbiological developments that would affect the stability of food products. In addition, they relate the interaction degree between the food matrix and its water content (Bell \& Labuza, 2000).

Sweet potato gummies showed initial moisture of $26.02 \%$, close to the values reported by Edward et al. (2002) for similar products, which considers that values close to $24 \%$ are adequate to obtain the desirable texture for this type of food. According to Fontana (2005), most confectionary products present water content between 0 and $22 \%$, depending on the formulation. Thus, for gummies made with gelatin, water and different concentrations of glucose syrup, isomalt and fructose, moisture percentage of 16 and $31 \%$ were obtained, where the gummies with glucose and fructose syrup as ingredients showed the highest value (Periche et al., 2015).

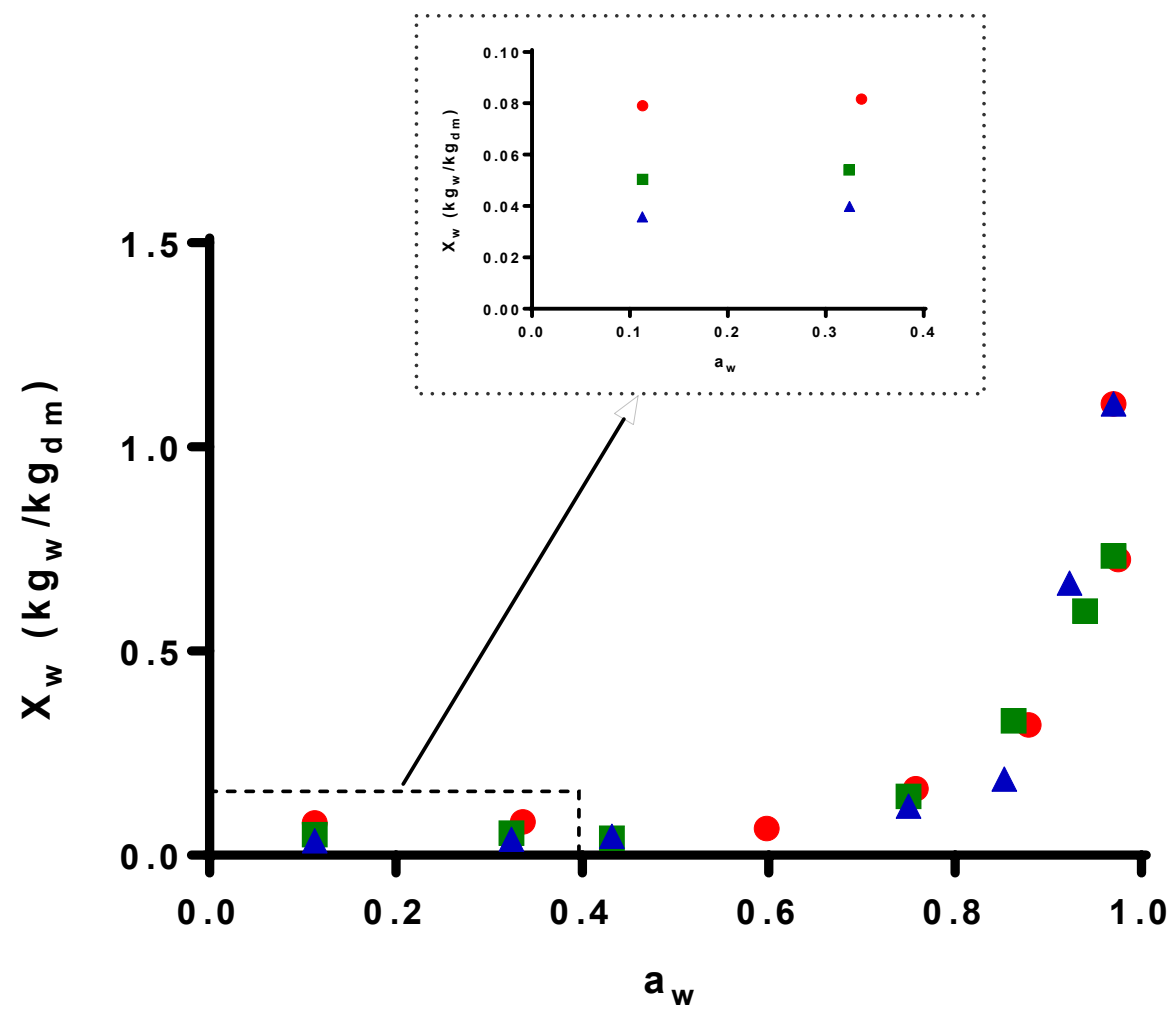

Figure 1. Sorption isotherm of sweet potato gummies at different temperatures, where: • corresponds to 4 , a a 20 y $\Delta$ a $30^{\circ} \mathrm{C}$. 
Figure 1 shows the sorption isotherms of sweet potato gummies developed by BIOTEC research group at different temperatures $\left(4,20\right.$ and $30{ }^{\circ} \mathrm{C}$ at atmospheric pressure). According to BET classification (Brunauer, Emmett, Teller, 1938), sorption isotherms exhibited a type III, characterized by a small amount of adsorbed water at low water activity and an abrupt increase after a certain relative humidity value. This behavior generally represents the sorption phenomena in biological materials, and is characterized by a J-shaped curve (Al-Muhtaseb et al., 2002). Similar results were obtained for confectionery products such as Turkish delight (Gögtüş et al., 1998), hard candies containing sorbitol and isomalt (Hadjikinova et al., 2003) and hard candies with sucrose and citric acid (Netramai et al., 2018).

As can be appreciated in Figure 1, at low values of $\mathrm{a}_{\mathrm{w}}$, the equilibrium water content of the samples was greater at $4{ }^{\circ} \mathrm{C}$ than 20 and $30{ }^{\circ} \mathrm{C}$, indicating a higher water adsorption and suggesting a lower hygroscopicity of the gummies as this parameter increases (Iglesias \& Chirife, 1982). It can impact directly on the stability during storage, since they contain a smaller amount of water for the same value of $\mathrm{a}_{\mathrm{w}}$, at a constant temperature.

In contrast, $\mathrm{a}_{\mathrm{w}}$ values close to 0.8 , the equilibrium moisture content increased with the temperature, visualizing an inverse behavior to the one aforementioned. This can be explained by the fact that at low $\mathrm{a}_{\mathrm{w}}$ values water sorption is mainly affected by the biopolymers used in the formulation of gummies (gelatin and sweet potato starches). However, as $\mathrm{a}_{\mathrm{w}}$ increase, the water begins to be absorbed by the simple sugars (such as glucose, sucrose and fructose) and by other constituents of low molecular weight, decreasing the effect produced by the temperature and producing a change in the isotherms behavior.

On the other hand, the change in the water activity caused by the effect of the temperature is mainly due to the change in the retention, dissociation and to the physical state of the water or to the increase in the solubility of the solute (Rahman \& Labuza, 2007). In this context, the equilibrium moisture content decreases while the temperature increase at constant values of $\mathrm{a}_{\mathrm{w}}$. This is probably due to the effect of the increases of the water molecules energy or excitation at higher temperatures which produce the decrease of the attractive forces between them, allowing them to separate from their sorption sites. Furthermore, if the temperature remains constant, the moisture content increase when the $\mathrm{a}_{\mathrm{w}}$ is also higher (Mohamed et al., 2005).

Nowadays, there are no available data on the analysis and development of isotherms of sweet potato soft jellies with honey. However, research in other food matrices, explain that the inversion points of the isotherms depends on the composition of the food and the solubility of sugars (Saravacos, \& Stincheld, 1965), which is favored by high temperatures. In this context, Ceballos et al. (2009) have reported isothermal inversion point at $\mathrm{a}_{\mathrm{w}}$ values between 0.55 and 0.75 and above 0.7 for products with high sugar content such as fruits, peaches, raisins, currants, plums, cookies.

\section{Adjustments of the mathematical models of sorption isotherms}

In the literature there are numerous mathematical models that allow describing the behavior of food sorption; however, they are not accurate in the entire range of water activities nor are they adjusted in the same way for all types of food (Al-Muhtaseb et al., 2002). The most applied models for food matrices are BET and GAB models (Timmermann et al., 2001), however, there are other models that have been presented good adjustments (Torres et al., 2018; Muangrat, \& Nuankham, 2018). BET, GAB, Henderson, Halsey, Oswin, Peleg, Iglesias and Chirife, Smith, White and Eiring, Kuhn and Caurie models were applied to the 
experimental data obtained for sweet potato gummies, in order to determine which is best adjustment and also, to obtain the characteristic parameters for each model (Figure 2 part 1 and part 2).

- Experimental data $4{ }^{\circ} \mathrm{C} \longrightarrow$ Sorption isotherm model $4{ }^{\circ} \mathrm{C}$

- Experimental data $20^{\circ} \mathrm{C}-$ Sorption isotherm model $20^{\circ} \mathrm{C}$

$\Delta$ Experimentaldata $30^{\circ} \mathrm{C}-$ Sorption isotherm model $30^{\circ} \mathrm{C}$
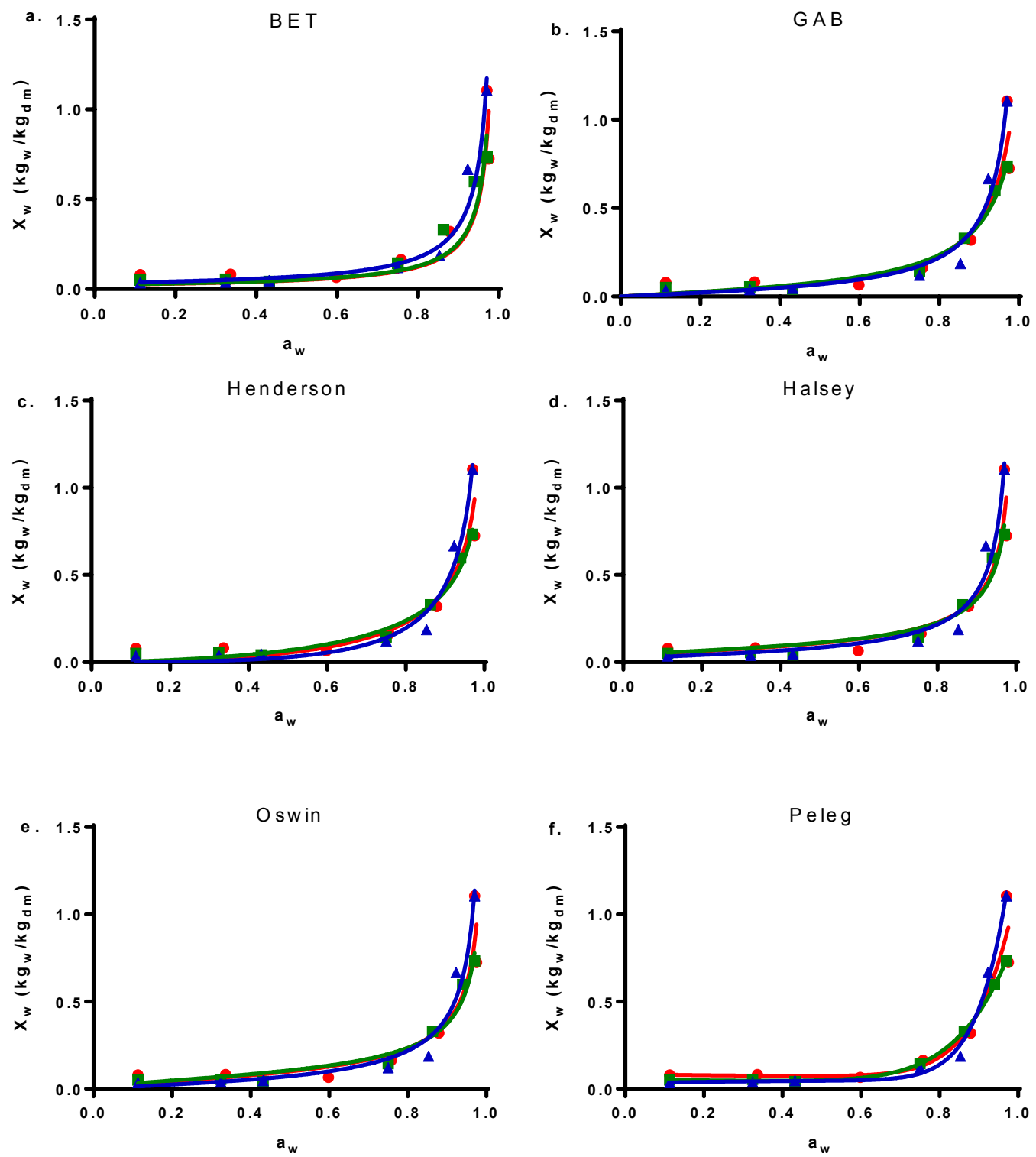

Figure 2 (part 1). Sorption isotherm of sweet potato gummies at different temperatures, where the points correspond to the experimental data and the lines the different mathematical models isotherms applied. 
- Experimental data $4{ }^{\circ} \mathrm{C} \quad$ - Sorption isotherm model $4{ }^{\circ} \mathrm{C}$
- Experimental data $20^{\circ} \mathrm{C} \quad$ Sorption isotherm model $20^{\circ} \mathrm{C}$
- Experimentaldata $30^{\circ} \mathrm{C} \quad$ Sorption isotherm model $30{ }^{\circ} \mathrm{C}$
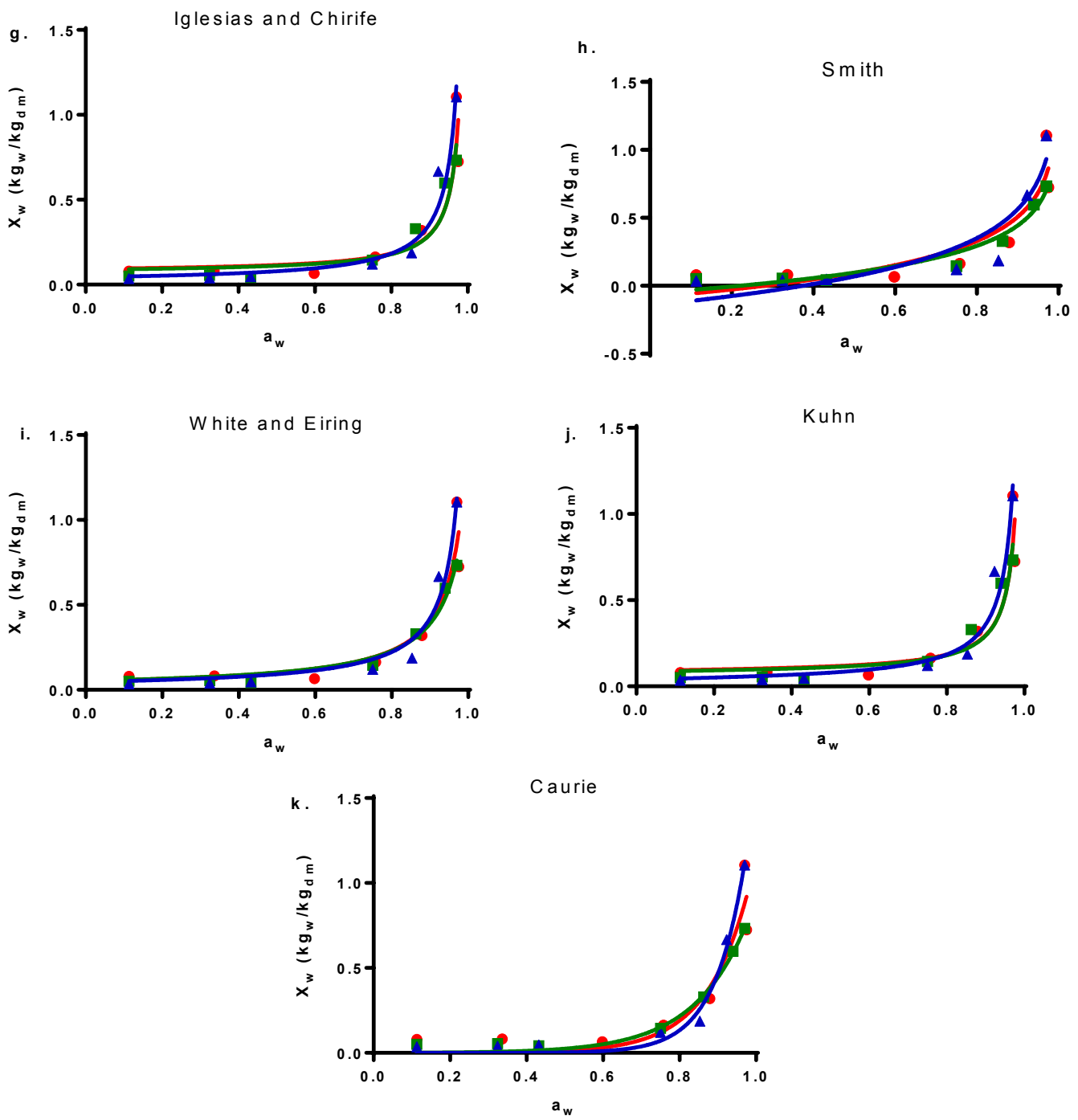

Figure 2 (part 2). Sorption isotherm of sweet potato gummies at different temperatures, where the points correspond to the experimental data and the lines the different mathematical models isotherms applied. 
Table 3 shows the obtained parameters of each model at three temperatures (4, 20 and $30{ }^{\circ} \mathrm{C}$ ) and the values of $\mathrm{R}^{2}$ and Sy.x. Peleg's model showed the best fit to the experimental data for all the studied temperatures, with correlation coefficients between 0.904-0.999 and standard deviations of the less than 0.177 . The best fit was obtained at 20 and $30^{\circ} \mathrm{C}$ with a $\mathrm{R}^{2}$ of 0.999 and Sy.x values of 0.007 and 0.054 , respectively. This model is purely empirical and it has the same or even better suitability than GAB model. However, it does not have the concept of the monolayer incorporated. It has also been used to describe the sorption isotherms of a large number of food products (Andrade et al., 2011).

Although, GAB model showed proper adjusted; it was not the best. Its analysis has the advantage of providing valuable thermodynamic information on the moisture content in the monomolecular layer $\left(\mathrm{X}_{0}\right)$, which is related to the stability of the product. Particularly, in the case of gummies, the values of $\mathrm{X}_{0}$ were in the order of $0.1087-0.1423\left(\mathrm{~kg}_{\mathrm{w}} / \mathrm{kg}_{\mathrm{dm}}\right)$, showing the lowest values at higher temperatures $\left(30^{\circ} \mathrm{C}\right)$. This behavior is possibly due to the damage of the active sites of the bonds between water and the solid phase of the material, caused mainly by the effect of temperature. In addition, as other researchers explain, high temperatures reduce the active sites on the surface of the product where water molecules bind, due to the reduction of hydrogen bonds.

On the other hand, $\mathrm{C}$ and $\mathrm{K}$ parameters allow understanding the adsorption behavior. The theoretical basis for the GAB sorption isotherm is the assumption of localized physical adsorption in multilayer, which is organized around a monolayer that surrounds the surface of the food matrix. The successive layers of water, beyond the multilayer, exhibit similar properties to the molecules of the liquid fraction. From the analysis of $\mathrm{C}$ and $\mathrm{K}$ parameters (Table 3), it could be understand that the process of water sorption present in gummies is characterized by the formation of a monolayer of molecules tightly attached to the surface of the food matrix ( $\mathrm{C}$ values close to the unit). The subsequent water molecules are slightly structured in a multilayer and have identical characteristics as the molecules belonging to the liquid fraction $(K=1)$. Likewise, $C$ values did not show a defined trend with the temperatures tested, keeping in the order of 0.8899 for $20^{\circ} \mathrm{C}$ and $0.9211-0.9666$ for 4 and $30{ }^{\circ} \mathrm{C}$, respectively. On the other hand, $\mathrm{K}$ parameter showed little variation with temperature, being the values obtained $0.9996 ; 0.9998$ and 0.999 for 4,20 and $30^{\circ} \mathrm{C}$, respectively.

Regarding the other applied models, Henderson's model showed a good fit at $20{ }^{\circ} \mathrm{C}\left(\mathrm{R}^{2}=\right.$ 0.963; Sy.x = 0.04), as well as the Caurie models $\left(R^{2}=0.9887\right.$; Sy.x $\left.=0.03323\right)$ and White and Eiring $\left(R^{2}=0.98\right.$; Sy.x $\left.=0.04413\right)$, at the same temperature.

The isotherm parameters obtained of all the above-mentioned models with their corresponding $\mathrm{R}^{2}$ and Sy.x values are presented in Table 3. 


\begin{tabular}{|c|c|c|c|}
\hline \multirow{2}{*}{ Model } & \multicolumn{3}{|c|}{ Temperature } \\
\hline & $4^{\circ} \mathrm{C}$ & $20^{\circ} \mathrm{C}$ & $30^{\circ} \mathrm{C}$ \\
\hline BET & $\begin{array}{c}X_{0}=0.0478 \\
C=200 \\
R^{2}=0.8241 \\
\text { Sy. } x=0.1850\end{array}$ & $\begin{array}{c}X_{0}=0.02567 \\
C=200 \\
R^{2}=0.8634 \\
\text { Sy.x }=0.1154\end{array}$ & $\begin{array}{c}X_{0}=0.03521 \\
C=93.6 \\
R^{2}=0.9493 \\
\text { Sy.x }=0.1021\end{array}$ \\
\hline GAB & $\begin{array}{c}X_{0}=0.1292 \\
C=0.9211 \\
K=0.9996 \\
R^{2}=0.8858 \\
\text { Sy.X }=0.1667\end{array}$ & $\begin{aligned} X_{0} & =0.1423 \\
C & =0.8899 \\
K & =0.9998 \\
R^{2} & =0.9872 \\
\text { Sy.X } & =0.03950\end{aligned}$ & $\begin{aligned} X_{0} & =0.1087 \\
C & =0.9666 \\
K & =0.9999 \\
R^{2} & =0.97 \\
\text { Sy. } X & =0.08784\end{aligned}$ \\
\hline Henderson & $\begin{array}{c}f=0.9517 \\
n=0.587 \\
R^{2}=0.8787 \\
\text { Sy.x }=0.1536\end{array}$ & $\begin{array}{c}f=1.079 \\
n=0.6711 \\
R^{2}=0.9831 \\
\text { Sy. } x=0.04060\end{array}$ & $\begin{array}{c}f=0.7283 \\
n=0.4436 \\
R^{2}=0.9742 \\
\text { Sy.x }=0.0782\end{array}$ \\
\hline Halsey & $\begin{array}{c}A=0.02319 \\
B=1.535 \\
R^{2}=0.8692 \\
\text { Sy.x }=0.1595\end{array}$ & $\begin{array}{c}A=0.02060 \\
B=1.605 \\
R^{2}=0.9605 \\
\text { Sy.x }=0.06203\end{array}$ & $\begin{array}{c}A=0.03565 \\
B=1.199 \\
R^{2}=0.9610 \\
\text { Sy.x }=0.08959\end{array}$ \\
\hline Oswin & $\begin{array}{c}A=0.09980 \\
B=0.6127 \\
R^{2}=0.8699 \\
\text { Sy.x }=0.1591\end{array}$ & $\begin{array}{c}A=0.1059 \\
B=0.5738 \\
R^{2}=0.9678 \\
\text { Sy.x }=0.05607\end{array}$ & $\begin{array}{c}A=0.07289 \\
B=0.7904 \\
R^{2}=0.9636 \\
\text { Sy.x }=0.08654\end{array}$ \\
\hline Peleg & $\begin{array}{c}A=1.110 \\
B=10.33 \\
C=0.07028 \\
D=0.06394 \\
R^{2}=0.9035 \\
\text { Sy.x }=0.1769\end{array}$ & $\begin{array}{c}A=0.04176 \\
B=0.09986 \\
C=0.8732 \\
D=7.491 \\
R^{2}=0.9997 \\
\text { Sy.X }=0.007048\end{array}$ & $\begin{array}{c}A=1.584 \\
B=12.88 \\
C=0.05111 \\
D=0.1558 \\
R^{2}=0.9916 \\
\text { Sy.x }=0.05363\end{array}$ \\
\hline $\begin{array}{l}\text { Iglesias and } \\
\text { Chirife }\end{array}$ & $\begin{array}{c}A=0.09334 \\
B=0.02248 \\
R^{2}=0.8452 \\
\text { Sy.x }=0.1735\end{array}$ & $\begin{array}{c}A=0.08811 \\
B=0.02273 \\
R^{2}=0.8992 \\
\text { Sy.x }=0.09913\end{array}$ & $\begin{array}{c}A=0.04409 \\
B=0.03476 \\
R^{2}=0.9497 \\
\text { Sy.x }=0.1018\end{array}$ \\
\hline Smith & $\begin{array}{c}A=0.08407 \\
B=0.2570 \\
R^{2}=0.8309 \\
\text { Sy.x }=0.1814\end{array}$ & $\begin{array}{c}A=0.05321 \\
B=0.2156 \\
R^{2}=0.9535 \\
\text { Sy.x }=0.06737\end{array}$ & $\begin{array}{c}A=0.1436 \\
B=0.3069 \\
R^{2}=0.8564 \\
\text { Sy.x }=0.1719\end{array}$ \\
\hline $\begin{array}{l}\text { White and } \\
\text { Eiring }\end{array}$ & $\begin{array}{c}A=19.12 \\
B=18.50 \\
R^{2}=0.8863 \\
\text { Sy.x }=0.1487\end{array}$ & $\begin{array}{c}A=18.72 \\
B=17.94 \\
R^{2}=0.98 \\
\text { Sy. } x=0.04413\end{array}$ & $\begin{aligned} A & =21.47 \\
B & =21.22 \\
R^{2} & =0.9641 \\
\text { Sy.x } & =0.08593\end{aligned}$ \\
\hline Kuhn & $\begin{array}{c}A=0.02243 \\
B=0.08376 \\
R^{2}=0.8455 \\
\text { Sy.x }=0.1734\end{array}$ & $\begin{array}{c}A=0.02267 \\
B=0.07845 \\
R^{2}=0.9005 \\
\text { Sy.x }=0.09850\end{array}$ & $\begin{array}{c}A=0.03466 \\
B=0.02940 \\
R^{2}=0.9501 \\
\text { Sy.x }=0.1014\end{array}$ \\
\hline Caurie & $\begin{array}{c}r=8260 \\
X_{s}=39.95 \\
R^{2}=0.8882 \\
\text { Sy.x }=0.1475\end{array}$ & $\begin{aligned} r & =1325 \\
X_{s} & =32.78 \\
R^{2} & =0.9887 \\
\text { Sy. } x & =0.03323\end{aligned}$ & $\begin{array}{c}r=274072 \\
X_{s}=54.15 \\
R^{2}=0.9856 \\
\text { Sy.x }=0.05450\end{array}$ \\
\hline
\end{tabular}

Table 3. Parameters obtained of the sorption isotherms models fitted for sweet potato gummies. 
Figure 3 shows the sorption isotherms of the sugars used in the preparation of the gummies (glucose, sucrose and fructose at $20{ }^{\circ} \mathrm{C}$ ) (Moreira et al., 2017), the sorption isotherm obtained for gummies and the Peleg's model (at the same temperature). As can be appreciated, the adsorption behavior of the gummies showed the similar tendency as the pure sugars solutions. At low $\mathrm{a}_{\mathrm{w}}$ values, the isotherm of the gummy was close to sucrose and fructose solutions curves, however at higher $\mathrm{a}_{\mathrm{w}}$, the behavior of the candy was intermediate between sucrose-fructose and glucose, demonstrating the influence of each added sugars for the entire $\mathrm{a}_{\mathrm{w}}$ range. On the other hand and regarding to the pure sugars, the moisture content (in dry basis) remained relatively low (and almost constant) until $\mathrm{a}_{\mathrm{w}}$ values corresponding to the point where the moisture increases abruptly. At this point, the crystals of the sugars begin to absorb water from the atmosphere and to dissolve them, phenomenon called deliquescence (Mauer \& Taylor, 2010).

The knowledge of this behavior could represent a suitable tool for the analysis of stability during gummies storage according to the predominant effect of each sugar.

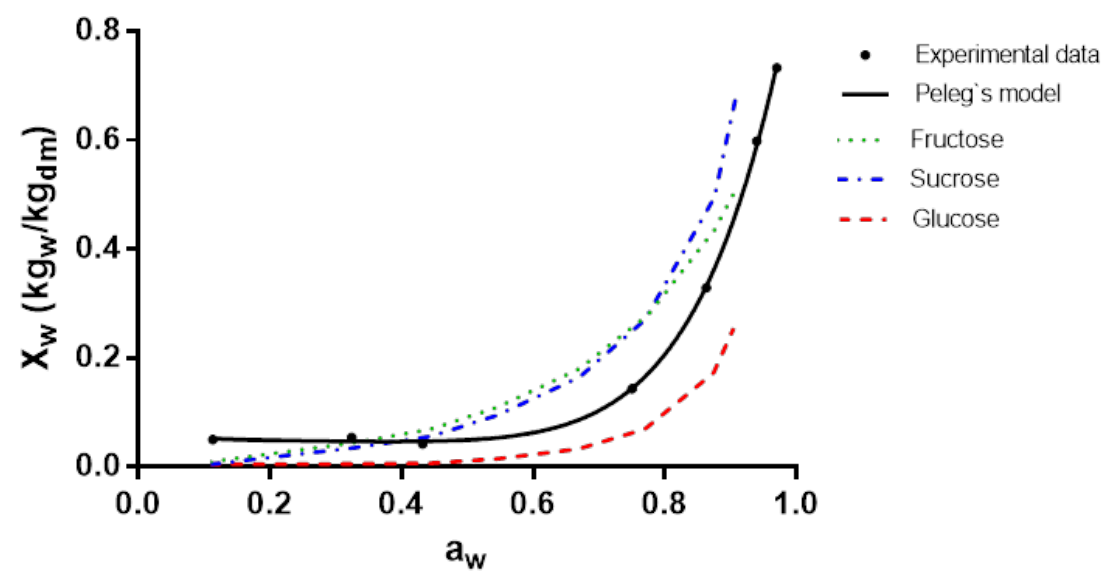

Figure 3. Sorption isotherms at $20^{\circ} \mathrm{C}$ of sucrose, glucose and fructose (adapted from Moreira et al., 2017), experimental data (gummies) and Peleg's model.

\section{Conclusions}

A healthy gummy based on a vegetable matrix has been developed.

Sorption isotherms of gummies at 4,20 and $30^{\circ} \mathrm{C}$ have been developed as a useful tool to control the shelf-life of gummies when exposed to different conditions during their processing and/or storage.

It has been demonstrated that the isopiestic gravimetric method is a valuable tool for the study of water sorption phenomenon, which in this case showed a Type III behavior. Several mathematical models have been successfully applied in order to fit the experimental data. Peleg's model showed the highest determination coefficients, thus, it can be considered as the good model to describe the moisture content in the equilibrium. This research showed that the development of candy based on sweet potatoes, honey and gelatin with edible 
coating represents a good option for obtaining healthy, stable and innovative products and it opens an opportunity for future works where the developed gummy can be used as a carrier of functional compounds such as fibers, proteins and polyphenols.

\section{Acknowledgements}

Authors acknowledge the financial support from SCTyP - UTN (Secretaría de Ciencia, Tecnología y Posgrado de la Universidad Tecnológica Nacional - Argentina) and PID UTNFRRe (project ALUTIRE0004517TC). 


\section{References}

Al-Muhtaseb, A. H., McMinn, W. A. M., and Magee, T. R. A. (2002). "Moisture sorption isotherm characteristics of food products: a review", Food and Bioproducts Processing, 80(2), 118-128.

Andrade, P., Ricardo, D., Lemus, M., Pérez, C., and Carmen, E. (2011). “Modelos de isotermas de sorción para alimentos: usos y limitaciones”, Vitae (Medellín), 18(3), 325-334.

Bahloul, N., Boudhrioua, N., and Kechaou, N. (2008). "Moisture desorption-adsorption isotherms and isosteric heats of sorption of Tunisian olive leaves (Olea europaea L.)", Industrial Crops and Products, 28(2), 162-176.

Bell, L. N. and Labuza, T. P. (2000). Moisture Sorption-Practical Aspects of Isotherm Measurement and Use (2nd ed.). Egan, USA. AACC Egan Press.

Boquet, R., Chirife, J., and Iglesias, H. A. (1978). "Equations for fitting water sorption isotherms of foods: II. Evaluation of various two-parameter models", International Journal of Food Science \& Technology, 13(4), 319-327.

Brunauer, S., Emmett, P.H. and Teller, E. (1938). "Adsorption of gases in multimolecular layers. Journal of American Chemistry Society”, 60 (1), 309-319.

Burey, P., Bhandari, B. R., Rutgers, R. P. G., Halley, P. J., and Torley, P. J. (2009). "Confectionery gels: A review on formulation, rheological and structural aspects", International Journal of Food Properties, 12(1), 176-210.

Caurie, M. (1971). "A practical approach to water sorption isotherms and the basis for the determination of optimum moisture levels of dehydrated foods", International Journal of Food Science \& Technology, 6(1), 85-93.

Ceballos, A. M., Giraldo, G. I., and Orrego, C. E. (2009). "Evaluación de varios modelos de isotermas de adsorción de agua de un polvo de fruta deshidratada", Vector, 107-117.

de Moura, S. C., Berling, C. L., Garcia, A. O., Queiroz, M. B., Alvim, I. D., and Hubinger, M. D. (2019). "Release of anthocyanins from the hibiscus extract encapsulated by ionic gelation and application of microparticles in jelly candy", Food Research International, 121, 542-552.

Ergun, R., Lietha, R., and Hartel, R. W. (2010). "Moisture and shelf life in sugar confections", Critical Reviews in Food Science and Nutrition, 50(2), 162-192.

Famá, L., Rojas, A. M., Gerschenson, L., and Goyanes, S. (2004). "Influencia del contenido de sorbato en el comportamiento mecánico a temperatura ambiente de películas comestibles”. Dissertation in CONAMET/SAM 2004 Congress, La Serena, Chile. 3 al 5 de noviembre.

Fontana, A.J. 2005. Water activity for confectionery quality and shelf-life. Manufacturing Confectionary, Decagon Devices, Inc. 45. Available at <http://aactcandy.org/firstpage/ a2005200511045.pdf $>$.

Gögtüş, F., Maskan, M., and Kaya, A. (1998). "Sorption isotherms of Turkish delight", Journal of Food Processing and Preservation, 22(5), 345-357.

Greenspan, L. (1977).” Humidity fixed points of binary saturated aqueous solutions”, 
Journal of Research of the National Bureau of Standards, 81(1), 89-96.

Guerrero-Coronilla, I., Morales-Barrera, L., and Cristiani-Urbina, E. (2015). "Kinetic, isotherm and thermodynamic studies of amaranth dye biosorption from aqueous solution onto water hyacinth leaves", Journal of Environmental Management, 152, 99-108.

Hadjikinova, M., Menkov, N., and Hadjikinov, D. (2003). "Sorption characteristics of dietary hard candy”, Czech Journal of Food Sciences, 21(3), 97-100.

Halsey, G. (1948). "Physical adsorption on non-uniform surfaces", The Journal of Chemical Physics, 16(10), 931-937.

Henderson, S.M. (1952). "A basic concept of equilibrium moisture", Agricultural Engineering, 33, 29-32.

Iglesias, H. A., and Chirife, J. (1982). Water sorption parameters for food and food components. Handbook of Food Isotherms. New York: Academic Press, 23-87.

Jiamjariyatam, R. (2018). "Influence of gelatin and isomaltulose on gummy jelly properties”, International Food Research Journal, 25(2), 776-783.

Kühn, I. (1964). "A new theoretical analysis of adsorption phenomena. Introductory part: The characteristic expression of the main regular types of adsorption isotherms by a single simple equation", Journal of Colloid Science, 19(8), 685-698.

Lemus, M, R. (2011). "Models of sorption isotherms for food: uses and limitations", Vitae, 18(3), 325-334.

Martínez, O. (2012). Report Spanish Confectionary Association. Produlce. Madrid, Spain. Mauer, L. J., \& Taylor, L. S. (2010). "Water-solids interactions: deliquescence”, Annual Review of Food Science and Technology, 1, 41-63.

Mohamed, A., Kouhila, M., Jamali, A., Lahsasni, S., and Mahrouz, M. (2005). "Moisture sorption isotherms and heat of sorption of bitter orange leaves (Citrus aurantium)", Journal of Food Engineering, 67(4), 491-498.

Moraga, G., Martínez-Navarrete, N., and Chiralt, A. (2006). "Water sorption isotherms and phase transitions in kiwifruit”, Journal of Food Engineering, 72(2), 147-156.

Moreira, R., Chenlo, F., Torres, M. D., and Prieto, D. M. (2017). "Statistical Criteria for Modelling of Water Desorption Isotherms of Sugars. Estimation of Sucrose Hygroscopic Properties from Glucose and Fructose Data”, Advances in Food Science and Engineering, I (1), 18-27.

Muangrat, R., and Nuankham, C. (2018). "Moisture sorption isotherm and changes in physico-mechanical properties of films produced from waste flour and their application on preservation quality of fresh strawberry", Food Science \& Nutrition, 6(3), 585-593.

Mutlu, C., Tontul, S. A., and Erbaş, M. (2018). "Production of a minimally processed jelly candy for children using honey instead of sugar”, LWT, 93, 499-505.

Netramai, S., Kijchavengkul, T., Sompoo, P., and Kungnimit, W. (2018). "The effect of intrinsic and extrinsic factors on moisture sorption characteristics of hard candy", Journal of Food Processing and Preservation, 42(5),

Oswin, C. R. (1946). “The kinetics of package life. III. The isotherm”, Journal of the Society 
of Chemical Industry, 65(12), 419-421.

Otálora, M. C., de Jesús Barbosa, H., Perilla, J. E., Osorio, C., and Nazareno, M. A. (2019). "Encapsulated betalains (Opuntia ficus-indica) as natural colorants. Case study: Gummy candies”, LWT, 103, 222-227.

Peleg, M. (1993). "Assessment of a semi-empirical four parameter general model for sigmoid moisture sorption isotherms 1", Journal of Food Process Engineering, 16(1), 21-37.

Periche, Á., Castelló, M. L., Heredia, A., and Escriche, I. (2016). "Stevia rebaudiana, Oligofructose and Isomaltulose as Sugar Replacers in Marshmallows: Stability and Antioxidant Properties”, Journal of Food Processing and Preservation, 40(4), 724-732.

Periche, A., Heredia, A., Escriche, I., Andrés, A., and Castelló, M. L. (2015). "Potential use of isomaltulose to produce healthier marshmallows", LWT-Food Science and Technology, 62(1), 605-612.

Rahman, M. S., and Labuza, T. P. (2007). Water activity and food preservation. Handbook of Food Preservation. FL: CRC Press, 465-494.

Rizvi, S. S. (2014). Thermodynamic properties of foods in dehydration. Engineering Properties of Foods. New York: CRC Press, 261-348.

Saravacos, G. D. and Stincheld, R. M. (1965). "Effect of temperature and pressure on the sorption of water by freeze-dried food materials", Journal of Food Science, 30, 779-786.

Smith, S. E. (1947). “The sorption of water vapor by high polymers”, Journal of the American Chemical Society, 69(3), 646-651.

Spiess, W. E. L., and Wolf, W. R. (1983). Results of the COST 90 project on water activity. Physical properties of foods. London: Applied Science, 65-91.

Talens, C., Castro-Giraldez, M., and Fito, P. J. (2018). "Effect of Microwave Power Coupled with Hot Air Drying on Sorption Isotherms and Microstructure of Orange Peel", Food and Bioprocess Technology, 11(4), 723-734.

Timmermann, E. O., Chirife, J., and Iglesias, H. A. (2001). "Water sorption isotherms of foods and foodstuffs: BET or GAB parameters?”, Journal of Food Engineering, 48(1), 19-31.

Torres, M. D., Chenlo, F., and Moreira, R. (2018). "Structural features and water sorption isotherms of carrageenans: A prediction model for hybrid carrageenans", Carbohydrate Polymers, 180, 72-80.

Traffano-Schiffo, M. V., Castro-Giraldez, M., Colom, R. J., and Fito, P. J. (2015). "Study of the application of dielectric spectroscopy to predict the water activity of meat during drying process", Journal of Food Engineering, 166, 285-290.

Traffano-Schiffo, M. V., Tylewicz, U., Castro-Giraldez, M., Fito, P. J., Ragni, L., and Dalla Rosa, M. (2016). "Effect of pulsed electric fields pre-treatment on mass transport during the osmotic dehydration of organic kiwifruit”, Innovative Food Science \& Emerging Technologies, 38, 243-251.

Van den Berg, C. (1984). "Description of water activity of foods for engineering purposes by means of the GAB model of sorption", Engineering Science in the Food Industry, 311-321. 